\title{
Heraldyka miast wielkopolskich w świetle dokumentów lokacyjnych (17.-18. w.) ${ }^{1}$
}

\section{Die Heraldik der großpolnischen Städte im Lichte der Lokationsurkunden (17.-18. Jhr.)}

1. Renesans badań nad polską heraldyka. 2. Właściciel miasta a znak miejski. 3. Rola aktu królewskiego. 3.1. Potwierdzenie znaku miejskiego. 3.2. Nadanie nowego znaku przy lokacji. 3.3. Pozostawienie realizacji decyzji o prawie do pieczęci praktyce. 3.4. Skuteczność królewskiej decyzji.

1. Die Renaissance der Forschungen nach polnischer Heraldik. 2. Der Stadtbesitzer und das Stadtzeichen. 3. Die Bedeutung der königlichen Akte. 3.1. Die Bestätigung des Stadtzeichens. 3.2. Die Verleihung neues Zeichens bei der Lokation. 3.3. Die Praxisüberlassung der Realisierung des Bescheides über das Siegelrecht. 3.4. Die Wirksamkeit des königlichen Beschlusses.

1. Renesans badań nad heraldyką miejską powodują dwie niezależne przyczyny. Pierwszą są rozwijające się według własnej logiki badania nad heraldyką polską. Już powstały prace na temat herbów średniowiecznego rycerstwa polskiego ${ }^{2}$ oraz polskich herbów ziemskich ${ }^{3}$. W naturalny więc sposób przyszła kolej na opracowanie następnej dziedziny heraldyki - polskiej heraldyki miejskiej. Druga przyczynę erupcji zainteresowań heraldyką miejską upatrywać należy w ustawie z 8 marca 1990 r., O samorzqdzie terytorialnym, mocą której ustawodawca oddał prawo ksztaltowania symboliki lokalnej do wylącznej wlaściwości rady Gminy ${ }^{4}$. Z tego powodu samorządy lokalne

${ }^{1}$ Zastosowane skróty: AGAD - Archiwum Główne Akt Dawnych w Warszawie; APP - Archiwum Państwowe w Poznaniu; APT - Archiwum Państwowe w Toruniu; Dz. Rkps. - Dział Rękopisów; Dz.U. - Dziennik Ustaw; KK - Księgi Kanclerskie; KW - Księgi Wpisów; MNK - Muzeum Narodowe w Krakowie; MNW - Muzeum Narodowe w Warszawie.

$\mathrm{Na}$ przestrzeni dziejów różnie wykreślano granice Wielkopolski, zob. J. Topolski, Wielkopolska. Robocza wersja hasla - materialy do dyskusji, Warszawa-Poznań 1986, s. 5-6. W prezentowanym artykule uwzględniamy miasta leżące na obszarze województw: poznańskiego, kaliskiego, sieradzkiego, łęczyckiego, inowrocławskiego, brzesko-kujawskiego, ziemi dobrzyńskiej i ziemi wieluńskiej.

${ }^{2}$ J. Szy ma ń ski, Herbarz średniowiecznego rycerstwa polskiego, Warszawa 1993, ss. 317.

${ }^{3}$ S. K. K u c zy ńs ki, Polskie herby ziemskie. Geneza, treści, funkcje, Warszawa 1993, ss. 334.

${ }^{4}$ Dz.U. 1990, nr 16, poz. 94, art. 18. 
bardzo często zwracają się do profesjonalistów (Polskie Towarzystwo Heraldyczne, Polskie Towarzystwo Historyczne, Zakłady Nauk Pomocniczych Historii) z prośbą o odtworzenie herbu swojej wspólnoty ${ }^{5}$. Z konieczności więc podejmowane są kwerendy źródłowe, przynoszące odkrycia nowych dokumentów, zawierających $\mathrm{m}$. in. wzmianki o herbach miast. $\mathrm{Z}$ dokumentów tych czasami dowiadujemy się o okolicznościach powstania godła, o jego rysunku oraz o motywach nadania mu określonego kształtu. Konfrontacja źródel pisanych $\mathrm{z}$ materiałem sfragistycznym pozwala prześledzić wzajemne relacje, zachodzące między znakiem nadanym a używanym później w polu miejskiej pieczęci. Możemy wówczas stwierdzić, czy nadany znak został zaakceptowany przez społeczność miejską, czy też i dlaczego został natychmiast przez nią odrzucony.

2. Głównym zamierzeniem autora jest przedstawienie losów herbów miast Wielkopolski, które powstały $w$ wyniku nadania monarszego. Powaga dokumentu opatrzonego królewskim podpisem winna gwarantować im trwałość, niezmienność i ochronę prawną. Rzeczywistość pokazała, iż powyższe stwierdzenie traktować należy jako założenie, od którego istniały jednak wyjątki. Praktyka akceptowała jednak decydujący wpływ właściciela ośrodka na kształt znaku jego miasta. Często utożsamiano więc symbol miasta $\mathrm{z}$ herbem właściciela, sprowadzając go tym samym wyłącznie do roli znaku własnościowego, modyfikowanego wraz ze zmianą dziedzica.

3. Nadania herbów dla miast polskich odbywaly się zazwyczaj przy okazji wystawienia dokumentu lokacyjnego. Jedynie bowiem społeczność obdarowana prawem miejskim, otrzymując ograniczoną autonomię, mogła decydować o swych wewnętrznych sprawach, mogła wystawiać dokumenty i uwierzytelniać je odciskami pieczęci, w których polu powinien wystąpić znak dysponenta.

3.1. Niektóre dokumenty lokacyjne - właściwie potwierdzenia lokacji - w akapitach poświęconych symbolice samorządowej odwoływały się do wcześniejszych ustaleń (nie znanych nam ze źródeł pisanych), a opisy i rysunki znaku urzędnicy kancelarii monarszej najczęściej wzorowali na pieczęciach miejskich, już używanych od chwili pierwszego nadania praw miejskich.

O potwierdzeniu znaku miejskiego mowa $w$ dokumencie lokacyjnym dla Odolanowa (woj. kaliskie) ${ }^{6}$ z 1637 r., wystawionym przez Władysława IV7,

${ }^{5}$ Por. H. Seroka, O problemach wspólczesnej heraldyki samorzqdowej, [w:] Polskie tradycje samorzadowe a heraldyka. Materialy $z$ sesji naukowej zorganizowanej $w$ dniach 4 i 5 czerwca 1991 r. w Lublinie, red. P. Dymmel, Lublin 1992, s. 127-137.

6 Przynależność administracyjna miast podawana jest według Mapy generalnej $i$ nowej dla calej Polski, Wielkiego Księstwa Litewskiego $i$ krajów sqsiadujacych..., wykonanej przez Bartolomeo Folina w 1770 r.

${ }^{7}$ APP, Akta miast, Odolanów, sygn. I/4. 
oraz $w$ jego późniejszym potwierdzeniu, dokonanym przez Stanisława Augusta z $1774 \mathrm{r}^{8}{ }^{8} \mathrm{~W}$ przywilejach z 1637 i $1774 \mathrm{r}$. znajdujemy zgodę ustawodawcy, aby miasto używało jako znaku murowanej bramy miejskiej $\mathrm{z}$ wieżą. $\mathrm{W}$ dokumencie podpisanym przez Władysława IV umieszczono uwage, iż opisany znak miasto używało od czasu pierwszej lokacji ${ }^{9}$, a ta nastąpiła ok. $1400 \mathrm{r}$.

Pieczęć Odolanowa $z$ ozdobną tarczą, bramą miejską, wieżą i chorągiewką na szczycie wieży pojawila się w 1572 r. O chronologii świadczy data $w$ legendzie otokowej ${ }^{10}$. Najprawdopodobniej i ta pieczęć była twórczym rozwinięciem wyobrażenia napieczętnego, używanego od średniowiecza.

O potwierdzeniu znaku miejskiego mówily dokumenty lokacyjne wydane dla Budzynia (woj. poznańskie). Pierwsza zachowana lokacja $\mathrm{z}$ opisem znaku pochodzi z $1641 \mathrm{r}$., choć znamy ją dopiero z potwierdzenia z $1773 \mathrm{r}^{11}$ Król Władysław IV stwierdzil, iż opisany w dokumencie z 1641 r. znak - pohuorła białego z kluczem - nawiązywal do pieczęci używanej przez miasto od czasu pierwszej lokacji, a ta nastapiła prawdopodobnie w czasie panowania króla Aleksandra (1501-1506) ${ }^{12}$, choć równie dobrze mogla nastąpić jeszcze przed $1458 \mathrm{r}^{13}$

Jedyna znana pieczęć Budzynia $\mathrm{z}$ okresu staropolskiego nosi $\mathrm{w}$ polu wyobrażenie opisane $w$ dokumencie Władysława IV, czyli $w$ pieczęci podzielonej w słup, w polu prawym heraldycznym połuorła bez korony, zaś w lewym polu heraldycznym - klucz ułożony poziomo, w ten sposób, że jego pióro wychodzi poniżej skrzydła połuorła ${ }^{14}$. Legenda, podając datę 1641, jednoznacznie informuje, iż pieczéć tę wykonano opierając się na postanowieniu dokumentu Władysława IV.

Istniejący stan rzeczy potwierdzala lokacja Nowego Bojanowa i Bogusławowa (woj. poznańskie), dokonana w 1663 r. przez Jana Kazimierza na prośbę Bogusława Bojanowskiego. Wśród katalogu przywilejów, którymi miały się cieszyć obie miejscowości, znajdujemy fragment mówiący o nadaniu pieczęci, której godło wypełnial herb Junosza, dla upamiętnienia osoby założyciela Bojanowa. Wokół pola miała biec legenda utworzona ze słów:

9 AGAD, Metryka Koronna, KK, nr 38, k. 288.

s APP, Akta miast, Odolanów, sygn. I/4.

10 MNK, Dz. Rkps., sygn. MNK 560 NI 119122; MNW, Dział Monet i Medali, sygn. 49697; APP, Ostrów Wlkp. cech kowali i ślusarzy, sygn. 1/28.

11 AGAD, KK, nr 38, s. 254-266.

12 Miasta polskie w Tysiącleciu, t. 2, Ossolineum 1967, s. 214.

13 O. Lange, Lokacje miast Wielkopolski wlaściwej na prawie niemieckim w wiekach średnich, Lwów 1925, s. 35.

14 MNK, Dz. Rkps., M. Gumowski, Katalog pieczęci $i$ herbów miejskich w ukladzie alfabetycznym, sygn. 1484 . 
Sigillum Oppidorum Nouorum Boianow et Boguslawow ${ }^{15}$. Jednakże lokacja z 1663 r. była kolejnym dokumentem wydanym dla Bojanowskich i dla Bojanowa. Marian Gumowski sądzil, iż już w 1583 r. Stefan Batory na prośbę Stanisława Bojanowskiego podniósł wieś Bojanowo do rzędu miast ${ }^{16}$. W dokumencie z $1663 \mathrm{r}$. znajdujemy z kolei informację o tym, iż w 1638 r. Stefan Bojanowski uzyskał od Władysława IV przywilej miejski. Zatem dokument z $1663 \mathrm{r}$. w istocie po części był potwierdzeniem przeprowadzonych lokacji, a we fragmencie dotyczącym Bogusławowa był nową lokacją.

Znamy m. in. pieczęć miejską Bojanowa, wyciśniętą na dokumencie z $1589 \mathrm{r}$. W jej polu widoczny jest kartusz herbowy, a w nim wyskakujący baran z krzaków róży ${ }^{17}$. Pieczęć powstała - jak świadczy o tym datacja dokumentu z jej odciskiem - tuż po pierwszej lokacji. Następne dokumenty wydane dla Bojanowa być może każdorazowo potwierdzały raz ustalony już rysunek godła napieczętnego. $Z$ całą pewnością godło napieczętne Bojanowa prezentuje pełną postać szlacheckiego herbu Junosza $\mathrm{z}$ odmianą, którym pieczętowali się Bojanowscy, a nie - jak sądzi M. Gumowski - jego formę uszczerbioną ${ }^{18}$.

3.2. Duża grupa dokumentów lokacyjnych samodzielnie kreowała kształt znaku miejskiego.

Swoją własną pieczęcią i własnym herbem posługiwała się Nowa Wschowa (woj. poznańskie), miasto założone na mocy przywileju Władysława IV w 1633 r. na prośbę Hieronima Radomickiego ${ }^{19}$.

$\mathrm{Z}$ tekstu dokumentu dowiadujemy się, iż $w$ tarczy podzielonej w slup umieszczono $w$ prawym złotym (żóltym) polu połuorła czerwonego, zaś w drugim lewym trzy strefy, z których dwie miały być czerwone, środkowa zaś srebrna (biała). Natomiast rysunek, na który powoływal się tekst dokumentu (hic artificis manu expressum est), zdecydowanie różnił się od opisu - połuorzeł byl biały, jego pole czerwone, skrajne strefy biake, a środkowa czerwona ${ }^{20}$. Zatem artysta poprawil „błędy" wystawcy aktu i samodzielnie nadał barwy w większym stopniu nawiązujące do heraldyki państwowej.

$\mathrm{Na}$ podstawie dokumentu powstała pieczęć miejska Nowej Wschowy. Sądzić należy, iż rytownik korzystał z rysunku, a nie $\mathrm{z}$ litery przywileju.

15 APP, Akta miast, Bojanowo, sygn. I/1, k. 4.

${ }_{16}$ M. Gu mowski, Pieczęcie $i$ herby miast wielkopolskich, Poznań 1932, s. 19.

17 MNW, Gabinet Monet i Medali, sygn. 49552; AGAD, Archiwum Piłsudskich-Gniatowiczów, Zbiór pieczęci miast polskich, sygn. 42-47; W. Wittyg, Pieczęcie miast dawnej Polski, Kraków 1905, s. 24.

${ }^{18} \mathrm{~W}$ polu czerwonym krzew różany, zza którego wyskakuje baran srebrny - por. S. Górzyński, J. Koch a nowski, Herby szlachty polskiej, Warszawa 1990, s. 74; M. Gumowski, Pieczęcie..., s. 19.

${ }^{19}$ H. Wuttke, Stadtebuch des Landes Posen von..., Leipzig 1864, nr 42.

20 Ibidem. 
W lewym heraldycznym polu pieczęci środkowa strefa miała być ciemniejsza (a więc czerwona) od pozostałych, skrajnych (a więc białych). Wynika to $\mathrm{z}$ widocznego ornamentu wygrawerowanego na powierzchni środkowej strefy. Prawe heraldyczne pole pieczęci wypełnia połuorzeł bez korony i bez insygniów władzy monarszej. Wokół pola biegł napis legendy z datą $1633^{21}$.

W 1638 r. Adam Olbracht Przyjemski uzyskał od Władysława IV przywilej lokacyjny dla Rawicza (woj. poznańskie). Wśród postanowień dokumentu znajdujemy fragment mówiący o znaku miasta. Dokładny opis uzupełniał barwny rysunek znaku. Godłem miasta został czarny niedźwiedź w polu złotym $^{22}$. Motyw ten zaczerpnięto $\mathrm{z}$ herbu A. O. Przyjemskiego - Rawa, który zostal tu uszczerbiony przez ujęcie panny $\mathrm{z}$ grzbietu niedźwiedzia ${ }^{23}$.

Pomimo iż tekst dokumentu oraz jego graficzne dopelnienie nie informowaly o tarczy, to jednak wszystkie znane pieczęcie miejskie Rawicza powtarzały ujęcie heraldyczne, a jedna $\mathrm{z}$ pieczęci nawet informowała za pomocą szrafirunku o barwach herbu ${ }^{24}$.

Także w 1638 r. Władysław IV na prośbę Krzysztofa Radziwiłła wydał dokument lokacyjny dla Obrzycka (woj. poznańskie) ${ }^{25}$. Dokument m. in. informował o nadaniu znaku, którego kształt, zgodnie z zapowiedzią dokumentu, powinien precyzyjnie określić artysta malarz. Jednakże akt ten znany jest tylko $\mathrm{z}$ wpisów, w których maksymalnie uproszczono zapis i jedynie w Metryce Koronnej znajdujemy nieudolną i nie ukończoną próbę wypowiedzi rysunkiem. Splątana kreska nie daje możliwości jasnej interpretacji. Dopiero konfrontacja ze źródłami sfragistycznymi pozwala na wyjaśnienie tajemniczego znaku z kart Metryki. W 1638 r. - świadczy o tym tekst legendy - władze miejskie otrzymały pieczęć, której godło tworzyła ozdobna tarcza, nakryta mitrą książęcą. W polu tarczy umieszczono róg jeleni w słup oraz trzy trąby myśliwskie, najprawdopodobniej przejęte $\mathrm{z}$ herbu Trąby Radziwiłłów ${ }^{26}$. Ten nieregularny kształt w Metryce był właśnie próbą wyrysowania rogu.

W 1697 r. - co również zostało odnotowane w legendzie - powstała nowa pieczęć Obrzycka $z$ mitrą i jednym rogiem myśliwskim. Rysunek tej pieczęci byl już celowym uproszczeniem wzorca $z$ nadania królewskiego ${ }^{27}$.

${ }^{21}$ M. Gu mowski, Pieczecie..., s. 379; APT, Katalog III, sygn. 5890, 5767, 5068.

22 APP, Akta miast, Rawicz, sygn. 1/1; APP, Księgi Grodzkie, Rel. Poznań, G. 684, k. 82v; O. H u p p, Wappen und Siegel der Deutschen Stadte, Heft 2 (Pommern, Posen und Schlesien), Frankfurt 1898, s. 40.

${ }^{23} \mathrm{~J} . \mathrm{K}$ a źmierczak, Rawicz. Gród Przyjemskich. Rys historyczny powstania i rozwoju miasta (1638-1938), Warszawa 1938, s. 22-23.

24 Insygnia miast polskich. Katalog wystawy, Poznań 1992, $\mathrm{nr} 94$, il. 44.

${ }^{25}$ AGAD, Metryka Koronna, KW, nr 183, k. 134 v.; APP, Księgi Grodzkie, Rel. Poznań G. 684, K. $154-154 \mathrm{v}$.

${ }^{26}$ MNK, Dz. Rkps., sygn. MNK 560 NI 119118, 119119; APP, Obrzycko cech krawców $7 / 10$.

27 AGAD, Archiwum Pilsudskich..., Zbiór pieczęci..., sygn. 423, 424. 
Herbem z królewskiego nadania szczyci się Kępno (ziemia wieluńska). W 1660 r. Jan Kazimierz na prośbę Adama Biskupskiego lokował Kępno i przy okazji określił znak miasta. Herbem został biały łabędź stojący na zielonej kępie, od której miasto wzięło nazwę ${ }^{28}$. Tekst dokumentu lokacyjnego powtarzały kolejne potwierdzenia przywilejów, dokonane przez Augusta III w 1752 i Stanisława Augusta w 1767 r. $^{29}$

Wszystkie znane pieczęcie Kępna konsekwentnie powtarzały godło opisane w $1660 \mathrm{r}$. Jedna $\mathrm{z}$ pieczęci podała datę powstania tłoka (rok 1661), choć równie dobrze data ta mogła informować o wydaniu przez właściciela Kępna - Adama Biskupskiego - ordynacji miejskiej (grudzień 1661 r.) ${ }^{30}$.

W 1662 r. król na prośbę Krzysztofa Grzymułtowskiego lokował Rakoniewice (woj poznańskie). Nadał mu wówczas prawo używania pieczęci, której godło tworzył odmieniony herb Nieczuja Grzymułtowskich: zamiast zaćwieczonego krzyża - ostrzew został przeszyty mieczem od góry z lewej w skos. Legenda umieszczona wokół ozdobnej tarczy informowała: SIGILLVM CIVITATIS FREISTAD ${ }^{31}$. Wkrótce po lokacji w 1662 r. - jak poświadcza legenda - powstała pieczęć miejska, będąca wierną kopią wzorca $\mathrm{z}$ dokumentu lokacyjnego ${ }^{32}$.

W 1726 r. August II, na prośbę Józefa Aleksandra Sułkowskiego, nadał herb miastu Frydrychsztat-Sokolniki (ziemia wieluńska). Lokacja z 1726 r. znana jest $z$ potwierdzenia dokonanego przez Stanisława Augusta Poniatowskiego z $1766 \mathrm{r}^{33}$ oraz odpisu dokumentu w późniejszej lustracji miasteczka ${ }^{34}$. $\mathrm{Z}$ nadania wynika, iż godłem miasta zostało Oko Opatrzności Boskiej, otoczone promieniami, przedzierającymi się przez obłoki, niżej Oka zaś umieszczono Orła z rozpostartymi skrzydłami, patrzącego w niebo. Opisane wyżej przedmioty heraldyczne pomieszczono w blękitnym polu. Wokól pola biegl napis: Oculi Omnium in te Sperant ${ }^{35}$.

Pieczęć miejska Frydrychsztatu z 1791 r. (o chwili jej wykonania informuje legenda otokowa) różni się od wzorca zaproponowanego $\mathrm{w}$ dokumencie. Orzeł został przesunięty ponad Oko Opatrzności Boskiej, zaś w jego miejsce umieszczono Ciołka - godło herbu króla Stanisława Augusta Poniatowskiego ${ }^{36}$. Ciołek prawdopodobnie wystąpil $\mathrm{w}$ związku ze wspo-

28 J. Kurzawa, S. Nawrocki, Dzieje Kepna, Kalisz 1982, s. 210.

29 APP, Akta miast, Kępno, sygn. I/5, I/4; AGAD, KK, nr 35, s. 185; O. Hup p, op. cit., s. 34 .

30 J. Kurzawa, S. Nawrocki, op. cit., s. 22.

31 APP, Akta miast, Rakoniewice, sygn. I/1.

${ }^{32}$ APP, Rakoniewice cechy, sygn. 8/6.

33 AGAD, KK, nr 28, s. 753.

34 AGAD, Archiwum Skarbu Koronnego, Oddział XLVI, nr 112, k. 12-13.

35 AGAD, KK, nr 28, s. 753.

${ }^{36}$ T. Olejnik, Pieczęcie $i$ herby miast ziemi wieluŕskiej, Lódź 1971, s. 56; MNK, Dz. Rkps., M. Gumowski, Katalog..., sygn. 1491. 
mnianym wyżej potwierdzeniem praw miejskich, dokonanym w $1766 \mathrm{r}$. właśnie przez Stanisława Augusta. Być może już wówczas (w 1766 r.) powstała pieczęć miejska, zastąpiona w 1791 r. nową, opisaną wyżej. Być może zmiana pieczęci podyktowana była ustawodawstwem miejskim Sejmu Wielkiego. Warto odnotować fakt, iż nadanie królewskie z 1726 r. miało ograniczony wpływ na kształt pieczęci. Myśl została wykorzystana, choć zmieniona tak, by wyróżnić nowego dobrodzieja miasta.

W 1752 r. August III na prośbę Macieja Malczewskiego założył Rostarzewo (woj. poznańskie). Obok postanowień typowych dla każdej lokacji znajdujemy informację o znaku miasta. August III zgodził się, aby Rostarzewo posługiwało się herbem utworzonym przez gwiazdę złotego koloru $\mathrm{w}$ polu czerwonym, z literami tegoż miasta, takim sposobem jak tu sa wyrażone. Całe szczęście, że poniżej znajdujemy rysunek pięknej, barokowej tarczy $\mathrm{z}$ korona, a w niej litery $\mathrm{R} \mathrm{M} \mathbf{R}$ w takim porządku, że pierwsza litera $\mathrm{R}$ została odwrócona $(\Re)$. Nad literą $\mathrm{M}$ umieszczono wspomnianą złotą gwiazdę sześciopromienną ${ }^{37}$. Opierając się na postanowieniach dokumentu, wykonano pieczęć, wiernie oddającą wzorzec z nadania. Drobne różnice dotyczyły rysunku tarczy. Ponadto uwage zwraca data 1754, umieszczona w polu pieczęci i informująca o chwili wykonania tłoka ${ }^{38}$.

3.3. Ciekawą drogę kreacji przeszedł herb Nowego Tomyśla (woj. poznańskie). Dokument lokacyjny, na prośbę Feliksa Szołdrskiego, wystawił w 1786 r. Stanisław August. W miejscu, gdzie zazwyczaj spotykaliśmy informacje o znaku miejskim, tym razem postanowiono, iż miasto znak albo pieczęć [...] taka iakq mu W. Dziedzic naznaczy mieć $i$ używać bédzie ${ }^{39}$. Wystawca przywileju $\mathrm{w}$ tym przypadku decyzje pozostawił w rękach właściciela. Ten z przyznanych mu praw skorzystał w 1788 r., nadając miastu pieczęć, której godło tworzył herb rodowy Szołdrskich - Lodzia, a legende tworzyło słowo (rozdzielone godlem napieczętnym) Neu-Tomischel ${ }^{40}$.

Na podstawie przywileju F. Szołdrskiego powstała pieczęć miejska. W jej polu wśród panoplii umieszczono owalną tarczę $\mathrm{z}$ herbem Lodzia. Nad tarczą położono koronę, a nad nią klejnot. Po bokach pióropusza data 1788 informowala o nadaniu herbu $\mathrm{i}$ wykonaniu tloka ${ }^{41}$.

Udało się wyodrębnić grupę decyzji monarszych, które nie zaowocowały powstaniem pieczęci $z$ nadanym godłem (a jeśli nawet powstały, to dziś nie są nam znane). Choć znak został określony, miasto nim obdarowane zrezygnowalo $\mathrm{z}$ jego manifestowania.

37 APP, Akta miast, Rostarzewo, sygn. I/3.

${ }^{38}$ MNK, Dz. Rkps., sygn. 563 NI 119642, 119643, 119644; AGAD, Archiwum Piłsudskich..., Zbiór pieczęci..., sygn. 556, 557, 558, 559; MNW, Dział Monet i Medali, sygn. 49752; APP, Wolsztyn cechy, 44/1.

${ }^{39}$ AGAD, KK, 80, cz. II, k. 25-31.

${ }^{40}$ T. Stroed i cke, Kurzgefasste Chronik der Stadt Neutomischel, Neutomischel 1888, s. 6.

41 APP, Poznań cechy 318/8; M. Gu mowski, Pieczecie..., s. 217. 
W 1629 r. Zygmunt III utworzyl dwa nowe miasta w obrębie Odolanowa. Jednym $\mathrm{z}$ nich był Zygmuntów (woj. kaliskie). W dokumencie znajdujemy informację, iż znakiem ośrodka zostało wyobrażenie św. Barbary Dziewicy i Męczenniczki. Artysta nie zdążył wypełnić pustego pola, pozostawionego na rysunek herbu. Nie znamy również pieczęci Zygmuntowa, co powoduje, iż niejasne są dla nas szczegóły tej kompozycji ${ }^{42}$.

Nie znamy żadnej pieczęci Lampartpola (woj. poznańskie) i jedynie postanowienia przywileju lokacyjnego informują nas o nadaniu znaku dla tego ośrodka. W 1641 r., na prośbę Lamparta Sierakowskiego, Władysław IV nadał miastu godło, przedstawiające leoparda złotego $\mathrm{z}$ lapami $\mathrm{w}$ prawo w polu czerwonym ${ }^{43}$. Godło miało być ilustracją imienia tudzież waleczności Sierakowskiego.

W 1644 r. Władysław IV na prośbę Alberta Gajewskiego wydal przywilej lokacyjny dla Zaborowa (woj. poznańskie), w którym znajdujemy opis pieczęci, jaką posługiwać się miało miasto. Godło tworzył miecz umieszczony pomiędzy dwoma księżycami w polu czerwonym, czyli byl to herb rodowy Gajewskich - Ostoja. Wobec tak dokładnego opisu, kancelaria monarsza zrezygnowała $z$ rysunku, powszechnie przecież znanego herbu ${ }^{44}$. Nie znamy żadnej pieczęci wykonanej według opisanego wzorca. Dopiero w 1654 r., po zmianie właściciela, powstała seria pieczęci miejskich Zaborowa, których głównym motywem były dwie glowy wołu z pierścieniami (kolcami) w nozdrzach, nawiązujące do godła szlacheckiego herbu Wieniawa Leszczyńskich, nowych panów Zaborowa ${ }^{45}$.

Nie zachowały się również źródła sfragistyczne Laskówki - lokacji w obrębie Nowego Miasta nad Wartą (woj. kaliskie). Pieczęć nadana w dokumencie lokacyjnym z 1645 r. przez Jana Kazimierza na prośbę Krzysztofa Grzymultowskiego, jednocześnie nawiązywała do herbu właściciela i wskazywała na miejski charakter ośrodka. W polu pieczęci w bramie miejskiej umieszczono godło herbu Nieczuja Grzymułtowskich. Wokół biegł napis SIGILLVM OPPIDI IN LASKÓWKA46. Jednakże Laskówka nigdy nie rozwinęła się $w$ poważny ośrodek miejski. Wkrótce została wchłonięta przez Nowe Miasto ${ }^{47}$.

42 APP, Akta miast, Odolanów, sygn. I/2.

43 APP, Księgi Grodzkie, Rel. Poznań, G. 687, k. 346.

44 APP, Akta miast, Zaborowo, sygn. I/1; APP, Księgi Grodzkie, Rel. Wschowa, G. 143, k. $812 \mathrm{v}$.

${ }^{45}$ MNK, Dz. Rkps., M. G u m ow sk i, Katalog..., sygn. 1493; M. Gu mow sk i, Pieczecie..., s. 389; APT, Katalog III, sygn. 5766, 4714.

46 APP, Akta miast, Nowe Miasto, sygn. I/1.

${ }^{47} \mathrm{~J}$. D y bziński, Rys historyczny Nowegomiasta nad Wartq, [w:] Dzieje Nowegomiasta n. Wartq $i$ jego Kurkowego Bractwa Strzeleckiego z okazji trzechsetlecia Bractwa, Nowe Miasto 1937 , s. $43-44$. 
W 1748 r. August III na prośbę Józefa Bętkowskiego wydał przywilej, w którym utworzył miasteczko Szamocin (woj. kaliskie) ${ }^{48}$. Tekst dokumentu informuje nas jedynie, iż miasto otrzymało prawo oznaczania dokumentów, opuszczających kancelarię miejską, znakiem, którego godło miały tworzyć litery tego miasteczka ${ }^{49}$. Brak rysunku powoduje, iż nie wiemy, o jakich literach myślał ustawodawca, oraz $w$ jakim układzie miały one wystąpić.

Do rekonstrukcji herbu miejskiego nie możemy chyba wykorzystać pieczęci uznanych przez M. Gumowskiego za własność Szamocina. Ich godła tworzyły wyobrażenia dwóch ryb i sfery. Legenda odczytana przez M. Gumowskiego miała informować: R[ęczna] P[ieczęć] M[iasta] S[zamocina]. Wątpliwości dodatkowo budzi fakt, iż odciski tych znaków pochodzą jeszcze z XVII w., a więc sprzed lokacji miasta ${ }^{\text {so }}$.

Bardzo niejasne są sformułowania dotyczące znaku miejskiego nadanego dla Nowej Izbicy Kujawskiej (woj. brzesko-kujawskie) w 1754 r. przez Augusta III, na prośbę Jana Skarbka. W tekście znajdujemy sformulowanie mówiące o nadaniu pieczęci albo znaku zwanego „Janana”, w polu czerwonym $^{51}$. Nie wiemy, jak powinna wyglądać owa „Janana”, gdyż miejsce na wyrysowanie znaku do dziś nie zostało wypełnione. Nie znamy żadnej pieczęci Nowej Izbicy, a godło wcześniejszej pieczęci Izbicy Kujawskiej nawiązywało do herbu właścicieli ośrodka - Dołęgi Kretkowskich ${ }^{52}$.

$\mathrm{Z}$ całą pewnością pod zagadkowym slowem „Janana” nie kryła się nazwa herbu szlacheckiego Janina. Kancelaria monarsza być może chciala poinformować odbiorców dokumentu o nadaniu „znaku Jana” bądź ,znaku Janowego".

W 1846/47 r. mieszkańcy Izbicy zgłosili projekt herbu, w którym czerwoną tarczę wypełniała srebrna lękawica - godło herbu Awdaniec oraz 8 złotych gwiazd. Argumentowano, iż owe gwiazdy symbolizują pionierów, którzy dokonali pierwszej lokacji miasta, zaś lękawica oznaczała udział Jana Skarbka w lokacji Nowej Izbicy ${ }^{53}$.

Również bez możliwości konfrontacji z materiałem sfragistycznym pozostaje dokument Stanisława Augusta z 1786 r., wystawiony dla Radzymina (woj. kaliskie), na prośbę Józefa Radzymińskiego. Dokument stanowił, iż znakiem miasta będzie jeleń - godło wyznaczone przez dziedzica ${ }^{54}$.

$48 \mathrm{~J}$. Szelmeczka, Szamocin $i$ jego dzieje. Jednodniówka z okazji 600-lecia powstania Szamocina 1364-1964, Szamocin 1965, s. 13.

49 APP, Księgi grodzkie, Rel. Kcynia G. 143, k. 173v.

${ }^{50}$ M. Gumowski, Pieczęcie..., s. 341-342.

51 AGAD, Dokumenty pergaminowe, sygn. 4305 .

52 W. Wittyg, op. cit., s. 92.

${ }^{53}$ MNK, Dz. Rkps., M. Gu m ow sk i, Katalog..., sygn. 1484.

${ }^{54}$ APP, Księgi Grodzkie, Rel. Gniezno, G. 232, k. 804 v; AGAD, KK, nr 80, cz. II, k. 38. 
W kilku przypadkach ustawodawca nie określił wyobrażenia znaku miejskiego. Odwoływał się do ikonografii, której jednak w dokumentach często brakowało. Monarcha pozostawial wiẹc sprawę herbu miejskiego codziennej praktyce, zezwalał na jego oddolną, samodzielną kreację.

W 1629 r. Zygmunt III nadal prawa miejskie dla Konstancji (woj. kaliskie) - wydzielonej części Odolanowa. W tekście dokumentu nie znajdujemy żadnej wskazówki co do ksztaltu i tematu herbu ${ }^{55}$.

W 1638 r., na prośbę Krzysztofa Radziwiłła, Władysław IV lokował miasto Radziwilów (woj. poznańskie) ${ }^{56}$. Jednakże ustawodawca w tekście nie zamieścił opisu herbu, odwołując się jedynie do dzieła malarza. Jednakże, ze względu na charakter przekazu - jest to wpis - widzimy jedynie rysunek nieregularnego, niczym nie wypełnionego prostokąta.

W 1731 r. August III, na prośbę Stanisława i Marianny Niszyckich oraz Antoniego i Franciszki Szembeków, lokowal Trzciankę (woj. poznańskie). I tym razem ustawodawca, mówiąc o herbie, odwoływal się do rysunku, który jednak nie zostal wykonany ${ }^{57}$. Być może brak przesądzającej decyzji wiązał się ze skomplikowaną sytuacją własnościową Trzcianki. Możliwe, że Niszyckim i Szembekom nie udało się uzgodnić, który herb rodowy powinien zdobić pieczęć miasta ${ }^{58}$.

Nie znamy pieczęci powstałych bezpośrednio po lokacji (w 1731 r.) Trzcianki. Dopiero w 1738 r. - a świadczy o tym legenda - wykonano pieczęć, której pole wypełniała owalna tarcza z Ciołkiem Poniatowskich - nowych wlaścicieli Trzcianki ${ }^{59}$. Stanislaw Poniatowski sprzedał w 1755 r. Trzciankę Józefowi Lasockiemu, co doprowadziło do powstania kolejnej pieczęci, której godłem była już Dołęga Lasockich ${ }^{60}$.

3.4. Przedstawiony materiał pozwala na sformułowanie kilku wniosków. Niektóre miasta Wielkopolski (21 ośrodków według obecnego stanu badań) otrzymały, potwierdzone przywilejem, prawo używania znaku miejskiego. Odbywało się to zawsze podczas lokacji ośrodka. Nadanie znaku miejskiego było jednym $\mathrm{z}$ wielu postanowień dokumentu lokacyjnego i - jak można sądzić - traktowano je jako mniej ważną decyzję. Przedmiotem nadania królewskiego - co wynika $\mathrm{z}$ używanej terminologii ${ }^{61}$ i ze sposobu prezentacji

55 APP, Akta miast, Odolanów, sygn. I/1.

s6 AGAD, Metryka Koronna, KW, nr 183, k. 132v.

${ }^{57}$ S. Lam parski, Przywilej lokacyjny miasta Trzcianki, Trzcianka 1988, s. 8, 15.

s8 Ibidem, s. 8.

59 S. Lamparski, Pieczęcie herbowe miasta Trzcianki. Informator, Trzcianka i98i, s. 5-6, tabl. Ia.

${ }^{60}$ Ibidem, s. 6, tabl. Ib.

61 W dokumentach wydanych dla: Zygmuntowa, Konstancji, Nowej Wschowy, Odolanowa, Obrzycka, Radziwiłowa, Rawicza, Budzynia, Lampartpola na oznaczenie nadawanego znaku użyto słowa insigne. Termin sigillum wystąpił $w$ dokumentach wystawionych dla Zaborowa, 
graficznej ${ }^{62}$ - był znak, który mógł jednocześnie pełnić funkcję pieczęci i herbu miejskiego. O jego charakterze i zastosowaniu decydował jego dysponent.

Przywileje mogły zatwierdzać znak używany przez miasto nawet od średniowiecza lub też mogły go samodzielnie kreować. Istniały również nadania, $w$ których ustawodawca rezygnowal $\mathrm{z}$ jasnego określenia rysunku godla, pozostawiając to użytkownikom.

Niektóre nadane godła nie zostały zaakceptowane przez wspólnoty miejskie lub wlaścicieli ośrodków. Znane są przypadki odstępowania od wyznaczonych znaków. O porzuceniu wyznaczonego znaku decydowała płynność stosunków własnościowych, ambicje nowych właścicieli, słabość małych ośrodków miejskich, czy wreszcie ich efemeryczny charakter. Należy również pamiętać, iż w okresie staropolskim nie wyksztalcily się organy nadzorujące przestrzegania prawideł heraldycznych. Herby $i$ heraldykę miast polskich $\mathrm{w}$ równym stopniu kształtowały $\mathrm{i}$ wola królewska, i praktyka.

Bojanowa. W dokumentach dla Laskówki znajdujemy podwójną terminologię - stemma seu sigillum, w nadaniu dla Kepna - insigne seu sigillum, a w dokumencie dla Rakoniewic - stemma seu sigillum. W nadaniach dla Szamocina, Rostarzewa, Izbicy Kujawskiej, Radzymina, Nowego Tomyśla występuje terminologia polska - znak albo pieczẹć.

${ }_{62} \mathrm{~W}$ dokumentach pojawiały się barwione rysunki lub opisy, które czasami podawały kolorystyke. 